\title{
Feeding Adult of Artemia salina (Crustacea-Branchiopoda) on the dinoflagellate Gyrodinium corsicum (Gymnodiniales) and the Chryptophyta Rhodomonas baltica
}

\author{
Rauquírio André Albuquerque Marinho da Costa $^{1 *}$, Maria Luise Koening ${ }^{2}$ and Luci \\ Cajueiro Carneiro Pereira ${ }^{3}$ \\ ${ }^{1}$ Laboratório de Plâncton e Cultivo de Microalgas (LPCM); Núcleo de Estudos Costeiros; Campus Universitário de \\ Bragança; Universidade Federal do Pará; Alameda Leandro Ribeiro, s/n; Aldeia; 68600-000; Bragança - PA - \\ Brasil. ${ }^{2}$ Departamento de Oceanografia; Universidade Federal de Pernambuco; Av. Arquitetura, s/n; Campus \\ Universitário; Cidade Universitária; 50739-540; Recife - PE - Brasil. ${ }^{3}$ Laboratório de Oceanografia Costeira e \\ Estuarina; Campus Universitário de Bragança; Universidade Federal do Pará; Alameda Leandro Ribeiro, s/n; \\ Aldeia; 68600-000; Bragança - PA - Brasil
}

\begin{abstract}
Experiments were carried out on feeding performance and survival rates of adult Artemia salina exposed to no axenic strains of the dinoflagellate Gyrodinium corsicum and of the Chryptophyta Rhodomonas baltica. Filtration

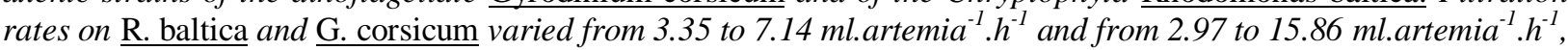
respectively. The ingestion rates observed for $\mathrm{A}$. salina did not indicate any digestive dysfunction or physiological impairment for organisms fed on $\mathrm{G}$. corsicum and their functional response were similar to those observed for other organisms like copepod fed on different food concentrations. Mortality rates oscillated from $2.5 \%$ to $100 \%$ when A.


corsicum indicated that this dinoflagellate presented a hazard effect on $\mathrm{A}$. salina that was not possible to confirm if it was related to toxin production or to nutritive inadequacy of this dinoflagellate as food for organisms of this species.
\end{abstract}

Key words: Feeding, Artemia salina, Rhodomonas baltica, Gyrodinium corsicum

\section{INTRODUCTION}

Blooms of harmful algae increased in coastal waters around the world during the last decades (Anderson, 1989; Hallegraeff et al., 1988; Sournia et al., 1991; Smayda, 1992; 1997) which evidently would increase more in the future, given the increasing eutrophization (Lam and Ho, 1989; Okaichi, 1989; Hallegraeff, 1993) and global warming perspectives (Hallegraeff, 1993). Data available in the literature indicate that zooplankton grazing could generate a substantial impact on wild populations of toxic dinoflagellates (Turner and Anderson, 1983; Watras et al., 1985). However, other authors consider that production and liberation of toxic compounds would interfere with the feeding processes of some zooplanktonic organisms like copepods (Dutz, 1998; Teegarden, 1999; Maneiro et al., 2000). The potential reduction of toxic blooms and the transference of dinoflagellate toxins through the marine food webs by some zooplanktonic organisms must be

\footnotetext{
* Author for correspondence
} 
considered of great importance when dealing with feeding experiments that involve PSP toxin producers. Hence, it would be important to know whether dinoflagellates are only toxic to fish or also toxic to organisms at lower trophic levels in the pelagic food webs.

Gyrodinium corsicum Paulmier is an unarmoured dinoflagellate that was first reported for the saltwater lake of Diana in Corsica from which originates its denomination. This new species belongs to the order Gymnodiniales (family Gymnodiniaceae) and it was responsible for the development of outbreaks related with the mortality of important fishes such as gilthead seabream (Sparus aurata) and European seabass (Dicentrarchus labrax), caged in intensive aquaculture systems during massive blooms in Diana Lake (Paulmier et al., 1995) and other fish species in Alfacs Bay (Garcés, 1998). These authors did not discard the possibility of ichthyotoxin (haemolysins or allotoxins) production by organisms of this species although negative results were observed for samples collected in Corsica.

Rhodomonas baltica was used in our work as a non-toxic control because it presented similar dimensions of those observed for G. corsicum and has been commonly offered as food supply in aquaculture systems. The present study aimed to determine the feeding patterns of adult Artemia salina (Branchiopoda - Crustacea) exposed to variable cell concentrations of Gyrodinium corsicum (toxic dinoflagellate) and to compare the results with those obtained for Rhodomonas baltica (non-toxic algae control).

\section{MATERIAL AND METHODS}

\section{Food supply}

$G$. corsicum and $R$. baltica were selected due to similar cell size and their toxic and non-toxic nature, respectively. The used stocks were obtained from the Institute of Marine Sciences of Barcelona (I.C.M. Barcelona, Catalonia- Spain). The algae selected were strains of the dinoflagellate G. corsicum Paulmier, GCORS1 (I.C.M. - Barcelona) and the non-toxic Cryptophyta R. baltica Karsten (CCAP 979/9 UK from I.C.M. - Barcelona). The equivalente espherical diameter (ESD) of the used species were $12.61 \mu \mathrm{m}$ to $G$. corsicum and $7.53 \mu \mathrm{m}$ to $R$. baltica. The algae were batch-cultured at $15 \pm 1$ ${ }^{\circ} \mathrm{C}$ in an incubator under controlled temperature, light regime of 12:12 $\mathrm{h}$ light/dark cycle and a irradiance of $200 \mu \mathrm{mol} . \mathrm{m}^{-2} \cdot \mathrm{s}^{-1}$ (day-light fluorescence tubes). The cultures were maintained in $200 \mathrm{~mL}$ flasks containing $\mathrm{f} / 2$ medium (Guillard, 1975 ) in seawater at $35 \%$ salinity.

\section{Animal preparations for feeding}

Dried eggs of Artemia salina (L.) were obtained from New Technology Laboratories LTD, United Kingdom. A stock culture of Artemia was reared on $R$. baltica at $27 \pm 1{ }^{\circ} \mathrm{C}$. The stocks were then transferred to the same controlled environmental chamber cited for the culture of phytoplankton and maintained with this cell food during onegeneration time. All the Artemia used in the experiments were reared from adult females cultured under laboratory conditions. Before the experiments, adult organisms were sorted and placed in 1 liter beackers containing $800 \mathrm{ml}$ of $0.45 \mu \mathrm{m}$ filtered seawater, rinsed with filtered seawater and then transferred to the experimental bottles.

\section{Resistance to starvation}

To study the tolerance of adult individuals to the lack of food, 15 adult $A$. salina were transferred to $250 \mathrm{ml}$ bottles filled with $0.45 \mu \mathrm{m}$ Millipore filtered seawater and fixed to a rotate grazing wheel adjusted to $1 \mathrm{rpm}$. The bottles were examined every day and the dead organisms were recorded and discarded using a Pasteur pipette. All determinations were carried out with 4 replicates. A. salina adults were defined as dead when no movements were registered within $60 \mathrm{~s}$. Mortality rates were calculated as:

$$
M 24 H=(N M C / T C) \times 100(1),
$$

where: $\mathrm{M} 24 \mathrm{H}$ is the mortality rate after the $24 \mathrm{~h}$ trials, NMC is the number of non-motile Artemia in each flask after the $24 \mathrm{~h}$ trials and TC is the total number of organisms in each bottle. The $\mathbf{M}^{\prime \prime} \mathbf{X}^{\prime \prime} \mathrm{H}$ index was calculated in the same way for $48 \mathrm{~h}, 72 \mathrm{~h}$ and so on.

\section{Feeding experiments}

Fixed $6 \mathrm{~h}$ grazing trials were carried out at $15 \pm 1$ ${ }^{\circ} \mathrm{C}$ and low light levels to limit algae growth. 
Initial cell concentrations were performed using a Coulter electronic particle counter model TA II equipped with a $140 \mu \mathrm{m}$ aperture. Dilutions were carried out in $0.45 \mu \mathrm{m}$ filtered seawater to provide food suspensions that varied between 100 and

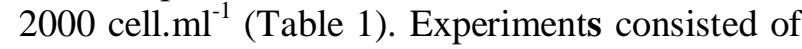
three bottles with grazers for each of the species (R. baltica or G. corsicum) and cell concentrations used, three growth control bottles for $R$. baltica (non-toxic algae) and three growth control bottles for $G$. corsicum. At the beginning of the experimental period the bottles were capped and affixed to a rotate grazing wheel, and rotated at 1 rpm until the end of the experiment. At the end of the experiment, containers were removed from the wheel and artemias were separated from the algae suspensions with mesh nets of $200 \mu \mathrm{m}$ and transferred to Millipore $0.45 \mu \mathrm{m}$ filtered seawater.
Filtration and ingestion rates were calculated according to Fernández (1979):

$$
\begin{gathered}
F=\left(\operatorname{Ln} C_{c^{-}}-\operatorname{Ln} C_{e}\right) / t \cdot(V / N)(2), \\
I=\left(C_{c^{-}} C_{e}\right) .(V / N t)(3),
\end{gathered}
$$

where:

$\mathrm{F}=$ filtration rate $(\mathrm{ml}$ of medium swept clear.artemia $\left.{ }^{-1} \cdot \mathrm{h}^{-1}\right)$;

$\mathrm{I}=$ ingestion rate (number of cells ingested.artemia ${ }^{-}$ $\left.{ }^{1} \cdot \mathrm{h}^{-1}\right)$;

$\mathrm{C}_{\mathrm{c}}=$ final algal concentration in control flasks;

$\mathrm{C}_{\mathrm{e}}=$ final algal concentration in the experimental flasks;

$\mathrm{t}=$ duration of the experiment in hours;

$\mathrm{V}$ and $\mathrm{N}=$ the respective volume $(\mathrm{ml})$ and number of Artemia in the experimental flasks.

Table 1 - Experimental conditions employed during the bioassays carried out with A. salina fed on R. baltica and $G$. corsicum.

\begin{tabular}{lccc}
\hline \multicolumn{1}{c}{ Algae species } & $\mathbf{n}^{*}$ & $\begin{array}{c}\text { F.C.*** } \\
\left(\mathbf{C e l l . m l ^ { - 1 }}\right)\end{array}$ & $\begin{array}{c}\text { Time } \\
\text { (h) }\end{array}$ \\
\hline R. baltica & 5 & $\begin{array}{c}150,200,350,500,700, \\
900,1500,2000\end{array}$ & 3 \\
G. corsicum & 5 & $150,200,350,500,700$, & 3 \\
& 5 & $900,1500,2000$ & \\
\hline
\end{tabular}

$* \mathrm{n}=$ Number of organisms/bottle

$* *$ F.C. $=$ Food concentration

\section{Statistical analysis}

One-way ANOVA was employed to verify the existence of significant differences between ingestion rates of $A$. salina on the different algae concentrations. Fisher's PLSD test was used to analyse differences between treatments using a significance level of 0.05 .

\section{RESULTS}

Starved adults of A. salina showed total mortality rates after $288 \mathrm{~h}$ of incubation in $0.45 \mu \mathrm{m}$ Millipore filtered seawater. Incubations with adult organisms fed on $R$. baltica demonstrated mortality rates of $2.5 \%$ after the same incubation period (Fig. 1) showing that this alga was appropriated to maintain Artemia cultures under laboratory conditions. On the other hand, it was not possible to complete the life cycle of A. salina with $G$. corsicum as food. A. salina fed on this dinoflagellate showed $100 \%$ mortality before attain adult stage.

Filtration rates obtained for A. salina fed on $R$. baltica and G. corsicum are given in Figures $2 \mathrm{~A}$ and $2 \mathrm{~B}$. Filtration rates on $R$. baltica varied from 3.35 to $7.14 \mathrm{ml}$.artemia ${ }^{-1} \cdot \mathrm{h}^{-1}$. For organisms fed on G. corsicum, filtration rates oscillated from 2.97 to 15. $86 \mathrm{ml}$.artemia ${ }^{-1} \cdot \mathrm{h}^{-1}$. 




Figure 1 - Mortality rates of starved adult A. salina (dashed circle) and organisms fed on $R$. baltica (open circle) and G. corsicum (open squares).
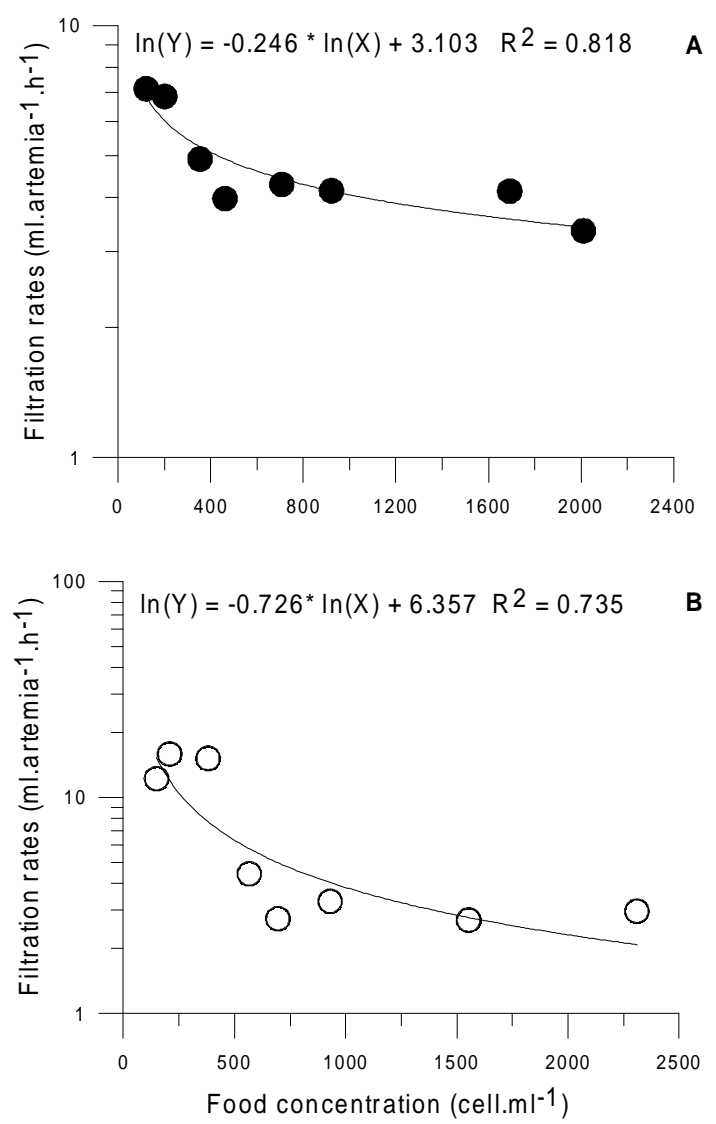

Figure 2 - Filtration rates $\left(\mathrm{ml} \cdot \operatorname{artemia}^{-1} \cdot \mathrm{h}^{-1}\right)$ of $A$. salina fed on different concentrations of R. baltica (A) and G. corsicum (B). 

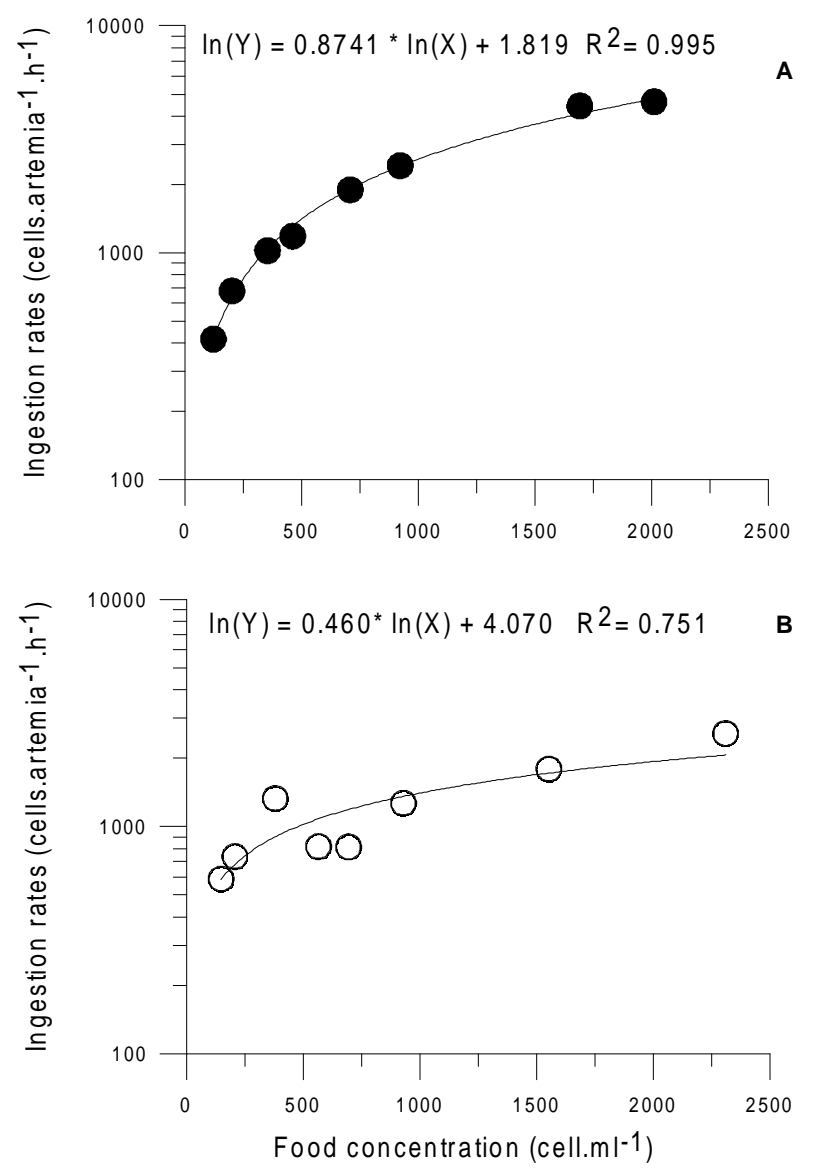

Figure 3 - Ingestion rates (cells.artemia ${ }^{-1} \cdot \mathrm{h}^{-1}$ ) of $A$. salina fed on different concentrations of R. baltica (A) and G. corsicum (B).

Maximal ingestion rates on $R$. baltica $\left(5.45 \times 10^{3}\right.$ cell. $\left.\mathrm{ml}^{-1}\right)$ and $G$. corsicum $\left(5.70 \times 10^{3}\right.$ cell. $\left.\mathrm{ml}^{-1}\right)$ were observed at the maximal food concentrations employed during the experiments $\left(\cong 2000\right.$ cells.ml $^{-}$ $\left.{ }^{1}\right)$. Significant differences $(\mathrm{p}<0.05)$ were found between ingestion rates on $R$. baltica and $G$. corsicum at low concentrations although it was not observed at high concentrations, except for 1500 cell.ml ${ }^{-1}$. Saturating concentrations were not observed neither for $R$. baltica or G. corsicum (Figs. $3 \mathrm{~A}$ and $3 \mathrm{~B}$ ).

\section{DISCUSSION}

Highest mortality rates observed for organisms fed on $G$. corsicum indicated that this dinoflagellate presented a hazardous effect on A. salina that was not possible to confirm if it was related to toxin production or to nutritive inadequacy of this dinoflagellate as food for organisms of this species. Results reported by Costa and Fernández (2002) using G. corsicum as food for Acartia grani and Euterpina acutifrons (Copepoda) showed no haemolytic activity for extracts of this dinoflagellate as it was suspected by other authors (Paulmier et al., 1995) indicating that the toxic effects of $G$. corsicum could be due to the presence of other toxins. The functional response of A. salina was similar to that observed for other organisms like copepod (Uye and Takamatsu, 1990; Liu and Wang, 2002) with higher filtration rates when fed on lower food concentrations $(\cong 8 \mathrm{x}$ $10^{2}$ cell. $\mathrm{ml}^{-1}$ ) and low filtration rates when exposed to high cell concentrations $\left(\cong 4 \times 10^{3}\right.$ cell. $\left.\mathrm{ml}^{-1}\right)$. Comparisons between Artemia filtration rates on both algae species were not carried out due to differences between alga dimensions. Some authors reported that differences in algae dimensions and shape (Frost, 1972; Nival and 
Nival, 1976) could interfere in the filtration efficiency of some organisms (copepod) capturing large cells efficiently than those of low dimensions.

For A. salina fed on planktonic algae, Reeve (1963) did not observe saturating ingestion rates

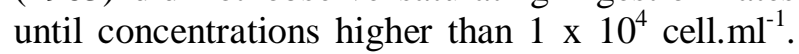
Saturating ingestion rates were also not observed in the present work where maximal cell concentrations were $2 \times 10^{3}$ cell.ml $^{-1}$. This functional response was similar to those registered for copepods were maximal ingestion rates were obtained when organisms were fed on the highest food concentrations employed in the experiments (Dutz, 1998; Frangópulos et al., 2000).

The ingestion rates observed for A. salina did not indicate any digestive dysfunction or physiological impairment for organisms fed on $G$. corsicum. Reduced ingestion rates of adult A. salina on $G$. corsicum could be an artefact related to differences of cell dimensions that implies in a higher carbon concentration in this species. So, to satisfy carbon requirements $A$. salina needs to ingest a low number of $G$. corsicum cells than it could be expected to $R$. baltica cells.

In summary it was possible to confirm that $A$. salina fed on R. baltica and G.corsicum. However, consequences of the ingestion of the later could be the responsable for the death of organisms in few days. On the other hand, $R$. baltica showed to be very efficient as food suply for adult A. salina giving survival rates of $97.5 \%$ after twelve days of incubation.

\section{RESUMO}

Experimentos foram desenvolvidos para estudar as taxas de alimentação e de sobrevivência de Artemia salina alimentada com cepas não tóxicas do dinoflagelado Gyrodinium corsicum e da Chryptophyta Rhodomonas baltica. As taxas de filtração sobre $R$. baltica e G. corsicum variaram entre 3,35 e $7,14 \mathrm{ml} \cdot \operatorname{artemia}^{-1} \cdot \mathrm{h}^{-1}$ e 2,97 e 15,86 ml.artemia ${ }^{-1} \cdot h^{-}$, respectivamente. As taxas de ingestão observadas para A. salina não indicaram disfunção digestiva ou prejuízo fisiológico nos organismos alimentados com G. corsicum, sendo a resposta funcional destes organismos similar a observada em copépodos alimentados com diferentes concentrações de alimento. As taxas de mortalidade de A. salina oscilaram entre $2,5 \mathrm{e}$ $100 \%$ quando alimentada com $R$. baltica e $G$. corsicum, respectivamente. As maiores taxas de mortalidade observadas para os organismos alimentados com G. corsicum indicam que este dinoflagelado apresenta algum efeito nocivo sobre A. salina, embora não tenha sido possível corfirmar se sua origem está relacionada com a produção de toxinas ou com a inadequação nutritiva deste dinoflagelado para alimentação de organismos desta espécie.

\section{ACKNOWLEDGMENTS}

This work was supported by CAPES ("Coordenação de Aperfeiçoamento de Pessoal de Nível Superior" - MEC, Brazil) through the concession of a Postgraduate fellowship. We are grateful to Dr. Maximino Delgado for providing the algae clones used in the experiments.

\section{REFERENCES}

Anderson J. and Reguera, B. (1989), Paralytic shellfish poisoning in northwest Spain: The toxicity of the dinoflagellate Gymnodinium catenatum. Toxicon, 27: (6), 665-674.

Costa R. M. and Fernández, F. (2002), Feeding and survival rates of the copepods Euterpina acutifrons and Acartia grani on the Chryptophyta Rhodomonas baltica and the dinoflagellates Alexandrium minutum and Gyrodinium corsicum. Journal of Experimental Marine Biology and Ecology, 33, 131-142.

Dutz, J. (1998), Repression of fecundity in the neritic copepod Acartia clausi exposed to the toxic dinoflagellate Alexandrium lusitanicum: relatioship between feeding and egg production. Marine Ecology Progress Series, 175, 97-107.

Fernández, F. (1979), Particle selection in the nauplius of Calanus pacificus. Journal of Plankton Research, 1: (4), 313-328.

Frangópulos, M. et al. (2000), Short-term and long-term effcts of the toxic dinoflagellate Alexandrium minutum on the copepod Acartia clausi. Marine Ecology Progress Series, 203, 161-169.

Frost, B. W. (1972), Effects of size and concentration of food particles on the feeding behaviour of the marine planktonic copepod Calanus pacificus. Limnology and Oceanography, 17, 805-817.

Garcés, E. P. (1998), Dinoflagellate proliferations in the catalan coast: in situ growth and maintenance adaptation studies. Ph.D. Thesis, Universidad de Barcelona. 254 pp. (In Catalan). 
Guillard, R. R. L. (1975), Culture of phytoplankton for feeding marine invertebrates. In: Smith, W. L. and Charley, M. M. (eds.). Culture of marine invertebrates animals. New York : Plenum. pp. 29-60.

Hallegraeff, G. M. (1993), A review of harmful algal blooms and their apparent global increase. Phycologia, 32: (2), 79-99.

Hallegraeff, G. M. et al. (1988), Three estuarine Australian dinoflagellates that can produce paralytic shellfish toxins. Journal of Plankton Research, 10, 533-541.

Lam, C. W. Y. and Ho, K. C. (1989). Red Tides in Tolo Harbour, Hong Kong. In: Okaischi T. et al. (eds.). Red Tides: Biology, environmental science and toxicology. New York : Elsevier. pp. 49-52.

Liu, S. and Wang, W. X. (2002), Feeding and reproductive responses of two marine copepods (Calanus sinicus and Paracalanus crissirostris) to toxic and nontoxic dinoflagellates and diatoms. Marine Biology, 140, 595-603.

Maneiro, I. et al. (2000), Zooplankton as a potential vector of diarrhetic shellfish poisoning toxins through the food web. Marine Ecology Progress Series, 201, 155-163.

Nival, P. and Nival, S. (1976), Particle retention efficiencies of an herbivorous copepod, Acartia clausi (adult and copepodit stages): Effects on grazing. Limnology and Oceanography, 21, 24-38.

Okaichi, T. 1989. Red tide problems in Seto Inland Sea, Japan. In: Okaischi, T. et al. (Eds.). Red Tides: Biology, environmental science and toxicology. New York : Elsevier. pp. 137-142.

Paulmier, G. et al. (1995), Gyrodinium corsicum nov. sp. (Gymnodiniales, Dinophycées), organisme responsable d'une "eau verte" dans l'etang marin de Diana (Corse), en avril 1994. Cryptogamie Algology, 16 : (2), 77-94.

Reeve, M. R. (1963), The filter-feeding of artemia I. In pure cultures of plant cells. Journal of Experimental Biology, 40, 195-205.
Smayda, T. (1992), Global Epidemic of Noxious Phytoplankton Blooms and Food Chains Consequences in Large Ecosystems. In: Sherman, K. et al. (eds.). Food chains, yields, models, and management of large marine ecosystems. Oxford: Westview Press. pp. 275-307.

Smayda, T. (1997), Bloom dynamics: Physiology, behaviour, trophic effects. Limnology and Oceanography, 42, 1132-1136.

Sournia, A. et al. (1991), Marine phytoplankton: how many species in the world ocean? Journal of Plankton Research, 13, 1093-1099.

Sykes, P. F. and Huntley, M. E. (1987), Acute physiological reactions of Calanus pacificus to select dinoflagellates: direct observations. Marine Biology, 94, 19-24.

Teegarden, G. J. (1999), Copepod grazing selection and particle discrimination on the basis of PSP toxin content. Marine Ecology Progress Series, 181, 163-176.

Turner, J. T. and Anderson, D. M. (1983), Zooplankton grazing during dinoflagellate blooms in a Cape Cod embayment, with observations of predation upon tintinnids by copepods. Marine Ecology, 4, 359-374.

Uye, S. and Takamatsu, K. (1990), Feeding interactions between planktonic copepods and red-tide flagellates from japanese coastal waters. Marine Ecology Progress Series, 59, 97-107.

Watras, C. J. et al. (1985), The effect of zooplankton grazing on estuarine blooms of the toxic dinoflagellate Gonyaulax tamarensis. Journal of Plankton Research, 7, 891-908.

Received: September 22, 2003; Revised: June 17, 2004; Accepted: March 08, 2005. 